\title{
EDITORIAL
}

Cita recomendada: Alvites-Huamaní, C. (2018) La Revisión por Pares Evaluadores en revistas científicas. Hamut'ay, 5(1), 5-6. http://dx.doi.org/10.21503/hamu.v5i1.1559

\section{La Revisión por Pares Evaluadores en REVISTAS CIENTÍFICAS}

Con la aparición de Internet el número de revistas científicas se ha incrementado de manera exponencial a nivel global, lo que ha traído como consecuencia un auge en la divulgación científica a través de la publicación de artículos. Este nuevo escenario ha generado que los editores responsables de estas publicaciones se replanteen sus políticas de revisión, con la finalidad de garantizar la calidad, factibilidad, consistencia y credibilidad de las investigaciones que se publican.

Una acción que se ha tomado en este sentido es poner un énfasis especial en la revisión por pares evaluadores externos a la revista, lo que en la actualidad se ha convertido en parte esencial del proceso editorial.

Este cambio implico pasar de una revisión a simple ciego, donde el par evaluador conocía quien era el autor del artículo, a otra manera de evaluar a doble ciego, en donde ni los autores ni revisores conocen sus identidades. El dictamen de los artículos se hizo anónimo con la finalidad de que la evaluación fuera imparcial y de esta manera, obtener juicios neutrales, así como sugerencias de modificaciones desde diferentes perspectivas académicas basadas en la experiencia de los revisores como expertos en la temática y la investigación.

Siguiendo la tendencia mundial, nuestra revista Hamut'ay ha considerado relevante acogerse a este proceso de revisión a doble ciego. Este sistema de revisión por pares adoptado desde nuestros inicios nos ha permitido dar transparencia al proceso editorial, reflexionar sobre nuestras líneas de investigación, mejorar la interpretación de los autores y poder diferenciar los errores que se puedan presentar en las investigaciones.

Además de apoyar en el proceso editorial se ha

\section{The Review by Peer Reviewers in Scien- TIFIC JOURNALS}

With the irruption of the Internet, the number of scientific journals has increased exponentially worldwide, which has resulted in a boom in scientific dissemination through the publication of articles. This new scenario has caused that the editors, who are responsible for these publications, rethink their revision policies, in order to guarantee the quality, feasibility, consistency and credibility of the published research.

In this regard, one action that has been taken into account is to put a special emphasis on external peer review, which has now become an essential part of the editorial process.

This change implied moving from a single blind review, where the reviewer knew who the author of the article was, to a double-blind peer review, where neither authors nor reviewers know their identities. The expert opinion on the articles was made anonymously in order to make the evaluation impartial, obtaining in this way neutral judgments, as well as suggestions for modifications from different academic perspectives based on the experience of the reviewers as experts in their subjects and research.

Following the global trend, our Hamut'ay journal has considered relevant to adopt this double-blind review process. This peer review process, embraced since our inception, has allowed us to give transparency to the editorial process, reflect on our research lines, improve the interpretation of the authors and to be able to differentiate the errors that may arise in the research papers.

Besides supporting the editorial process, it has become a tool for authors providing new approaches to their research or question some aspects to be improved or modified, or to be changed, 
convertido en una herramienta para los autores al brindarles nuevos enfoques de sus investigaciones o cuestionar algunos aspectos a mejorar o modificar, o bien que deban ser cambiados ajustándose al rigor científico que conlleva publicar un artículo. Esto no quiere decir que el par evaluador sea un corrector de estilo, sino que él sugiere desde su experticia, solo con el ánimo de brindar a los lectores una literatura académica acorde a los tiempos y al avance de las tecnologías.

Finalmente, hacemos mención, que existen otras opciones de revisión por pares, como es la abierta, sin embargo, no se ha descrito en este manuscrito, debido a que nuestra revista no está enfocada desde esa vertiente. pursuing the scientific rigor required when publishing an article. This does not mean that the peer reviewer is a proofreader, but the person who provides suggestions from his expertise, only with the aim of offering readers an academic literature according to the times and the advance of the technologies.

Finally, we mention that there are other options of peer review, such as the open review; however, it has not been described in this manuscript, since our journal is not oriented from that perspective.

Dra. Cleofé Genoveva Alvites Huamani Editor Jefe de la revista cientifica Hamut'ay I Editor in Chief of the Hamut'ay journal

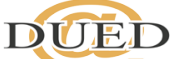

Dirección Universitaria de Educación a Distancia 